\title{
Activation of the ALK-5 Pathway is not per se Sufficient for the Antiproliferative Effect of TGF- $\beta 1$ on Renal Tubule Epithelial Cells
}

\author{
Omar García-Sánchez ${ }^{c}$ Sandra M. Sancho-Martínez $z^{b, c, d}$ \\ José Miguel López-Novoa ${ }^{b, c, d}$ Francisco J. López-Hernández ${ }^{a, b, c, d}$
}

\begin{abstract}
anstituto de Estudios de Ciencias de la Salud (IECSCYL)-Hospital Universitario de Salamanca, Unidad de Investigación, Salamanca, 'Instituto de Investigación Biomédica de Salamanca (IBSAL), Salamanca, unidad de Fisiopatología Renal y Cardiovascular, Departamento de Fisiología y Farmacología, Universidad de Salamanca, Salamanca, 'Fundación Renal Íñigo Álvarez de Toledo, Madrid, Spain
\end{abstract}

\section{Key Words}

TGF- $\beta$ • Cell proliferation • ALK-5 • Renal tubular epithelial cells

\begin{abstract}
Background/Aims: Defective tissue repair underlies renal tissue degeneration during chronic kidney disease (CKD) progression. Unbalanced presence of TGF- $\beta$ opposes effective cell proliferation and differentiation processes, necessary to replace damaged epithelia. TGF- $\beta$ also retains arrested cells in a fibrotic phenotype responsible for irreversible scarring. In order to identify prospective molecular targets to prevent the effect of TGF- $\beta$ during CKD, we studied the signaling pathways responsible for the antiproliferative effect of this cytokine. Methods: Tubule epithelial HK2 and MDCK cells were treated with TGF- $\beta$ (or not as control) to study cell proliferation (by MTT), cell signaling (by Western blot), cell cycle (by flow cytometry) and apoptosis (DNA fragmentation). Results: TGF- $\beta$ fully activates the ALK- 5 receptor pathway, whereas it has no effect on the ALK-1 and MAPK pathways in both HK2 and MDCK cells. Interestingly, TGF- $\beta$ exerts an antiproliferative effect only on MDCK cells, through a cytostatic effect in G0/G1. Inhibition of the ALK-5 pathway with SB431542 prevents the cytostatic effect of TGF- $\beta$ on MDCK cells. Conclusion: Activation of the ALK-5 pathway is not sufficient for the antiproliferative effect of TGF- $\beta$. The presence of undetermined permissive conditions or absence of undetermined inhibitory conditions seems to be necessary for this effect. The ALK5 pathway appears to provide targets to modulate fibrosis, but further research is necessary to identify critical circumstances allowing or inhibiting its role at modulating tubule epithelial cell proliferation and tubule regeneration in the context of CKD progression.
\end{abstract}

Copyright (c) 2015 S. Karger AG, Basel

Francisco J. López-Hernández

KARGER 125
Edificio Departamental, S-20 Campus Miguel de Unamuno, 37007 Salamanca, (Spain) Tel. +34923 294472, Fax +34923 294669, E-Mail flopezher@usal.es 


\section{Cellular Physiology Cell Physiol Biochem 2015;37:1231-1239 \begin{tabular}{l|l} 
and Biochemistry Published online: October 05, 2015 & $\begin{array}{l}\text { C } 2015 \text { S. Karger AG, Basel } \\
\text { www.karger.com/cpb }\end{array}$ \\
\hline
\end{tabular} \\ García-Sánchez et al.: ALK-5 and TGF- $\beta$-Induced Cytostasis}

\section{Introduction}

Chronic kidney disease (CKD) is a global epidemic with an increasing prevalence worldwide [1]. CKD comprises a group of pathologies in which the renal excretory function progressively and irreversibly decreases as a consequence of nephron loss due to glomerular or tubule cell deletion, fibrosis affecting both the glomeruli and the tubules, and renal vasculature alterations [2-4]. Patients may die to secondary conditions, the most important of which being cardiovascular events, or need renal replacement therapy in the form of renal transplant or dialysis [5]. It is estimated that $10-20 \%$ of the adult population have some degree of CKD, and that dialysis (applied on $0.1 \%$ of the population) consumes about $2 \%$ of the total health expenditure in many developed countries [6].

Traditionally, it was thought that the fibrotic process associated to CKD had its origin exclusively in the activation of local fibroblasts. However, other renal cell types have been lately identified as sources of fibrotic tissue components. Tubular epithelial cells can undergo epithelial-to-mesenchymal transition (EMT) to become myofibroblasts [7, 8]. Compared to tubule epithelial cells, myofibroblasts bear enhanced motility, increased proliferative and contractile capacity, and overproduce extracellular matrix elements contributing to fibrosis [4]. Tubular EMT has also been implicated in tubular tissue repair. Through the EMT, undamaged tubular epithelial cells would acquire the necessary phenotype to migrate and proliferate to substitute for death cells at neighbouring injury sites. At such points, dedifferentiated cells would then re-differentiate into TECs and synthesize extracellular matrix (ECM) components to rebuild the ECM and basement membrane, in a reverse process of mesenchymal to epithelial transition (MET) [4]. According to this model, under a pathological cytokine imbalance scenario typical of the CKD, MET would become skewed or interrupted and, consequently, dedifferentiated cells would not undergo the redifferentiation process and would continue to abnormally and ectopically produce ECM, leading to fibrosis and scarring [9]. A critical contributor for repair interruption may be a defective proliferation of tubular epithelial cells. The arrested tubular cells up regulate profibrotic cytokine production $[10,11]$. Accordingly, cell cycle-arresting mediators may alter the repair process and facilitate fibrosis.

Transforming growth factor- $\beta$ (TGF- $\beta$ ) has been shown to exert both anti-proliferative and pro-fibrotic effects $[2,4]$, and EMT [12]. TGF- $\beta$ is synthesized by various cell types including lymphocytes, macrophages, fibroblasts, myocytes, chondrocytes, astrocytes, epithelial cells, kidney cells and platelets [13]. TGF- $\beta$ induces the synthesis of ECM, and stimulates the production of protease inhibitors preventing normal enzymatic breakdown and turnover of the ECM [14]. TGF- $\beta$ membrane receptor complex comprises two families of proteins with serin-threonin kinase activity, namely type II (T $\beta$ RII) and type I (T $\beta R I)$ receptors. T $\beta R I$ includes activin-like kinase (ALK) receptors. TGF- $\beta$ binds to T $\beta R I I$, which then recruits T $\beta R$ I. The complex phosphorylates and activates several intracellular signaling cascades, including the small mothers against decapentaplegic (Smads); mitogen-activated protein kinases, such as extracellular regulated kinase (ERK), p38 and Jun kinase; and integrin-linked kinase (ILK). These effectors modulate the expression of target genes [15, 16]. Measurement of the expression level of these target genes serves to determine the full activation (or lack of) of specific pathways. Activation of the ALK-1-Smad-1/5 pathway, ultimately leads to the expression of plasminogen activator inhibitor 1 (PAI-1); whereas activation of the ALK-5-Smad-2/3 pathway leads to inhibitor of differentiation 1 (Id-1) expression [17].

Identification of the signaling pathways involved in the antiproliferative and profibrotic effects of TGF- $\beta$ may lead to better understanding the pathological mechanisms underlying CKD progression. In the present study we aimed at unraveling the role of the ALK5 pathway in the antiproliferative effect of TGF- $\beta 1$ in renal tubule cells, in order to identify new pharmacological targets for more selective and specific therapeutic and preventive strategies for CKD. 


\section{Cellular Physiology Cell Physiol Biochem 2015;37:1231-1239 \begin{tabular}{l|l} 
and Biochemistry & $\begin{array}{l}\text { DOI: 10.1159/000430246 } \\
\text { Published online: October 05, } 2015\end{array}$ \\
\hline
\end{tabular} \\ García-Sánchez et al.: ALK-5 and TGF- $\beta$-Induced Cytostasis}

\section{Materials and Methods}

All reagents were purchased from Sigma (Madrid, Spain), except where otherwise indicated.

\section{Cell culture}

Tubular cell lines, namely Human Kidney (HK2) cells and Madin-Darby Canine Kidney (MDCK) cells, were used and grown in an atmosphere of $95 \%$ air and $5 \% \mathrm{CO}_{2}$ at $37^{\circ} \mathrm{C}$. MDCK were grown in DMEM medium (Bio Whittaker Labs, Rockland ME, USA) supplemented with $10 \%$ fetal calf serum (FCS, Bio Whittaker Labs), $0.66 \mathrm{mg} / \mathrm{mL}$ penicillin and $60 \mathrm{mg} / \mathrm{mL}$ streptomycin sulfate (Bio Whittaker Labs), HK2 were grown in RPMI 1640 (Bio Whittaker Labs) supplemented with $10 \%$ FCS, 1 mM L-glutamine, $0.66 \mathrm{mg} / \mathrm{mL}$ penicillin, $60 \mathrm{mg}$ / $\mathrm{mL}$ streptomycin sulfate, $5 \mathrm{mg} / \mathrm{mL}$ insulin, $5 \mathrm{mg} / \mathrm{mL}$ transferrin and $5 \mathrm{ng} / \mathrm{mL}$ selenium. Cells were seeded in $100 \mathrm{~mm}$ Petri dishes (Nunc, Roskilde, Denmark). MDCK and HK2 cells were treated for 15, 30, 60, 120 minutes and 24, 48, 96 hours with TGF- $\beta 1(0.1,0.3$ and $1 \mathrm{ng} / \mathrm{mL})$ (Upstate-Millipore, Madrid, Spain). In some experiments, the ALK-5 pathway was inhibited with the ALK-5 inhibitor SB431542 (Tocris Bioscience, Bristol, UK). Representative photographs (x200) were obtained of MDCK and HK2 cells treated with $1 \mathrm{ng} /$ mL TGF- $ß 1$ (or vehicle, as control). Cell proliferation and cell death, and the underlying signaling involved were studied.

\section{Cell viability/proliferation by the MTT assay}

Viable cell number was determined by incubating cell cultures with $0.5 \mathrm{mg} / \mathrm{mL} 3$-[4.5-dimethylthiazol2-yl]-2.5-diphenyl tetrazolium bromide (MTT) for $4 \mathrm{~h}$. Then, $10 \% \mathrm{SDS}$ in $0.01 \mathrm{M} \mathrm{HCl}$ was added 1:1 (vol/vol) and left overnight at $37^{\circ} \mathrm{C}$. Finally, absorbance was measured at $570 \mathrm{~nm}$.

\section{Cell viability by propidium iodide exclusion}

Cells were incubated for $15 \mathrm{~min}$ with $50 \mathrm{lg} / \mathrm{mL}$ propidium iodide (PI, Sigma Aldrich) in the dark. Immediately, cells were analyzed by flow cytometry for PI fluorescence (FLH- 2) in a FACScalibur cytometer (BD Pharmingen).

\section{Cell cycle analysis}

Thirty minutes before harvest, $10 \mu \mathrm{M}$ 5-bromo-2-deoxyuridine (BrdU, Sigma Aldrich) was added to the cell culture. Subsequently, cells were fixed in ice-cold $70 \%$ ethanol overnight and stained with $0.01 \mathrm{mg} /$ $\mathrm{mL}$ anti-BrdU-FITC antibody (Abcam, Cambridge, United Kingdom). Then, $0.01 \mathrm{mg} / \mathrm{mL}$ PI was added to cell suspensions and 1 hour later they were analyzed by flow cytometry (FACScalibur, BD Pharmingen) with the CellQuest software. Singlet discrimination was done by means of an FL2-A versus FL2-W representation.

\section{DNA fragmentation}

DNA fragmentation was determined by ELISA with the commercial kit Cell Death Detection Plus (Roche Diagnostics, Barcelona, Spain) according to the manufacturer's instructions. Ten micrograms of protein were used from each cell extract.

\section{Nuclear integrity analysis}

Cells in cover slips were fixed with $4 \%$ paraformaldehyde, washed with phosphate buffered saline with calcium and magnesium (PBS Ca-Mg: $1 \mathrm{mM} \mathrm{CaCl}, 1 \mathrm{mM} \mathrm{MgSO}$, 0.81\% ClNa, $2.6 \mathrm{mM} \mathrm{PO}{ }_{4} \mathrm{H}_{2} \mathrm{~K}, 4.1$ $\mathrm{mM} \mathrm{PO}_{4} \mathrm{HNa}_{2}$ ), permeabilyzed with $0.1 \%$ Triton $\mathrm{X}-100,0.2 \% \mathrm{BSA}$ and $0.5 \%$ sodium azide, quenched with $\mathrm{NH}_{4} \mathrm{Cl} 50 \mathrm{mM}$ in PBS Ca-Mg. Nuclei staining was performed by 5 min incubation with $2 \mathrm{mM}$ Hoechst 33258 (Molecular Probes, Madrid, Spain) in a dark chamber. Cover slips were mounted on slides using Prolong gold antifade (Molecular Probes, Madrid, Spain). Fluorescence images were taken using a Zeiss Axiovert 200M microscope and a Zeiss LSM 510 confocal module (Zeiss, Madrid, Spain), with a HeNe laser with 543-excitation for rhodamine and Hg laser with 365-excitation.

\section{Western blot}

Protein extracts were obtained in extraction buffer $(140 \mathrm{mM} \mathrm{NaCl}, 20 \mathrm{mM}$ Tris- $\mathrm{HCl} \mathrm{pH}=7.5,0.5 \mathrm{M}$ ethylenediaminetetraacetic acid -EDTA-, 10\% glycerol, 1\% Igepal CA-630, $1 \mu \mathrm{g} / \mathrm{mL}$ aprotinin, $1 \mu \mathrm{g} / \mathrm{mL}$ leupeptin, $1 \mu \mathrm{g} / \mathrm{mL}$ pepstatin A, $1 \mathrm{mM}$ phenylmethylsulphonyl fluoride-PMSF-). Thirty micrograms from each 


\section{Cellular Physiology Cell Physiol Biochem 2015;37:1231-1239 \begin{tabular}{l|l|l|}
\cline { 2 - 2 } DOI: 10.1159/000430246 & O 2015 S. Karger AG, Basel
\end{tabular} and Biochemistry Published online: October 05, 2015 www.karger.com/cpb \\ García-Sánchez et al.: ALK-5 and TGF- $\beta$-Induced Cytostasis}

cell extract were separated by electrophoresis in 10-15\% acrylamide gels (Mini Protean II system, BioRad, Madrid, Spain). Immediately, proteins were electrically transferred to an Immobilon-P membrane (Millipore, Madrid, Spain). Membranes were probed with antibodies against cyclin E (Santa Cruz Biotechnology, Santa Cruz, CA), cyclin A (Santa Cruz Biotechnology, Santa Cruz, CA), $\beta$-actin (Abcam, Cambridge, UK), E-cadherin (Santa Cruz Biotechnology, Santa Cruz, CA), P-Smad 1 (Cell Signaling, Danvers, MA), P-Smad 2 (Cell Signaling, Danvers, MA), P-Akt (Cell Signaling, Danvers, MA), P-Erk (Santa Cruz Biotechnology, Santa Cruz, CA), Erk-1 (Santa Cruz Biotechnology, Santa Cruz, CA) and PAI-1 (Abcam, Cambridge, UK), followed by horseradish peroxidaseconjugated secondary antibodies and chemluminiscent detection (Immobilon Western Chemiluminescent HRP Substrate kit, Millipore) with photographic films (Kodak, Madrid, Spain). Densitometric quantification of bands was performed with the Scion Image software (Scion Corporation; Frederick, MD, USA).

\section{Statistical analysis}

Data are represented as the average \pm standard error (SEM) of $n$ experiments performed, as indicated in each case. Statistical comparisons were assessed by the one-way ANOVA analysis followed by the post hoc Tukey's test for multi-group comparisons, and the Student's t test for comparison between two groups. A p $<0.05$ was considered statistically significant.

\section{Results}

TGF- $\beta 1$ fully activates the ALK-5/Smad-2 pathway in MDCK and HK2 cells

Figure 1 shows the effect of incubating HK-2 and MDCK cells during short and long periods of time (up to 2 hours and up to 4 days, respectively) on intracellular signaling known to be activated by TGF- $\beta$ through the stimulation of the ALK- 1 and ALK-5 receptors. In both of cell lines, TGF- $\beta$ activated Smad-2, which indicated prior activation of the ALK- 5 receptor. This was evidenced by an increased phosphorylation of Smad-2, and an increased level of PAI-1, the protein product of a target gene in the Smad-2 pathway. Smad-1, Erk and Akt were not further activated by TGF- $\beta$, as revealed by the absence of additional phosphorylation of these proteins after short and long term exposure to the cytokine. This suggests that, in the present conditions, TGF- $\beta 1$ does not activate the ALK-1/Smad-1 pathway.

Fig. 1. Intracellular signaling activated by TGF- $\beta 1$ in HK2 and MDCK cells. Representative images of Western blot analysis (of $n=3$ independent experiments) of the amount of P-Smad2, P-Smad1, P-Akt, P-Erk, PAI-1 and total Erk of cell extracts from MDCK and HK2 cells treated for 15, 30,60 or 120 minutes with 0 or $1 \mathrm{ng} / \mathrm{mL}$ TGF-ß1 (a) and 24, 48 or 96 hours with 0 or $1 \mathrm{ng} / \mathrm{mL}$ TGF- $\beta 1$ (b).

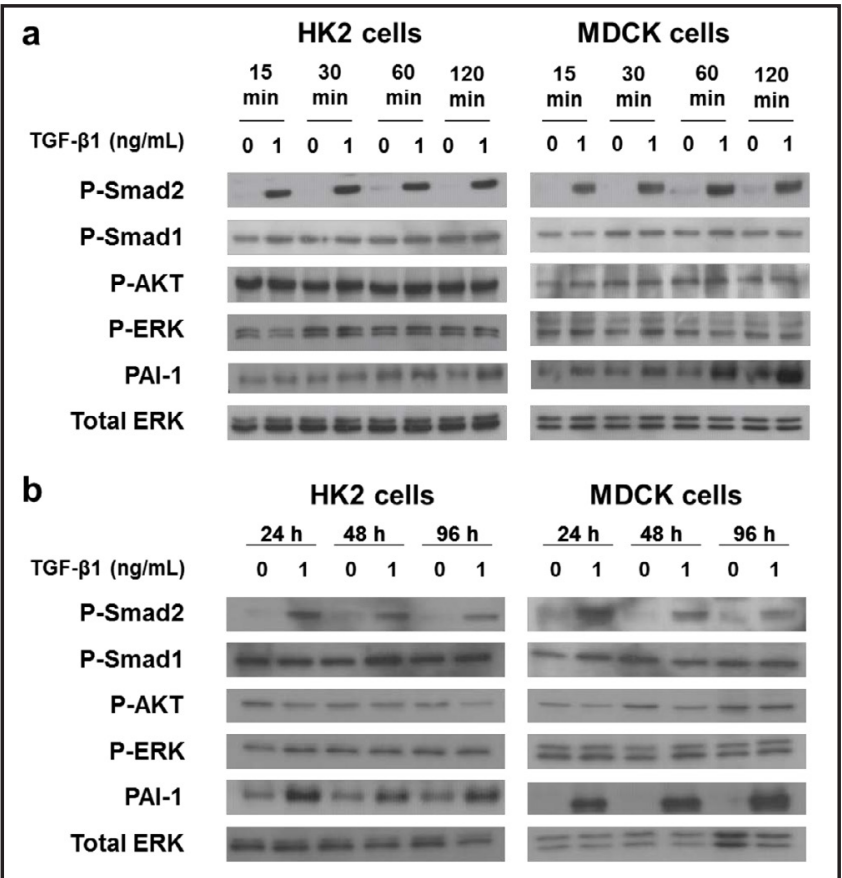


a

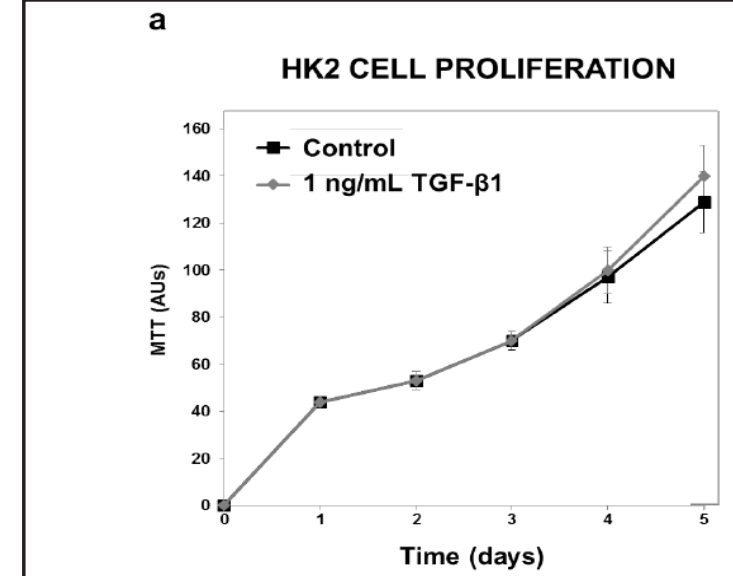

\section{b}

\section{MDCK CELL PROLIFERATION}

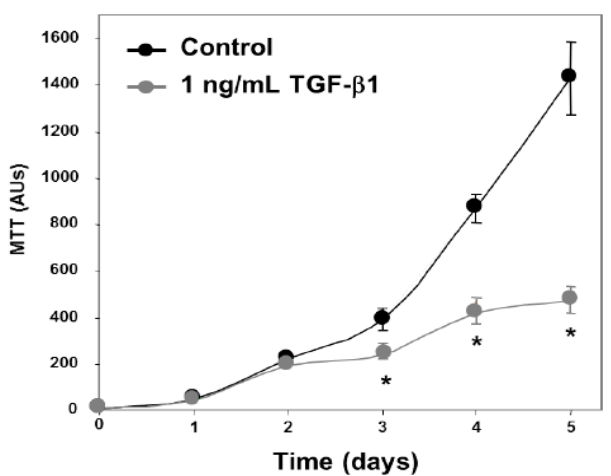

Fig. 2. TGF- $\beta$ reduces proliferation of MDCK but not of HK2 cells. MDCK and HK2 cells were treated for 5 days with 0 or $1 \mathrm{ng} / \mathrm{mL}$ TGF- $\beta 1$. At the end, an MTT assay was performed. Data represent the average \pm SEM of $n=3$ independent experiments performed in triplicate. ${ }^{*} p<0.05$ with respect to the same time point in the control group. AUs, arbitrary units.

a

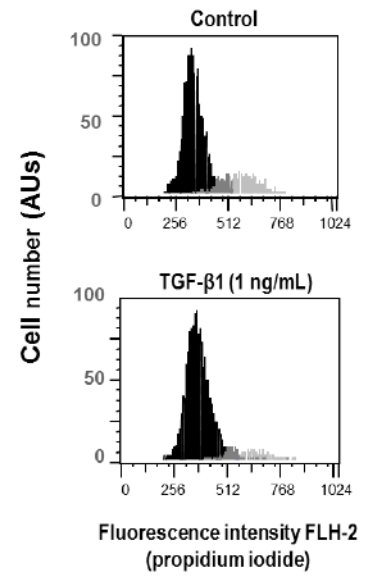

b

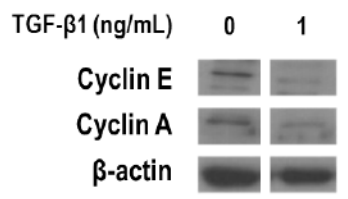

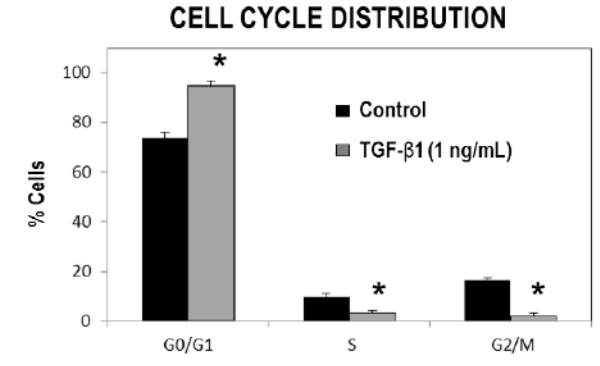

CYCLINE

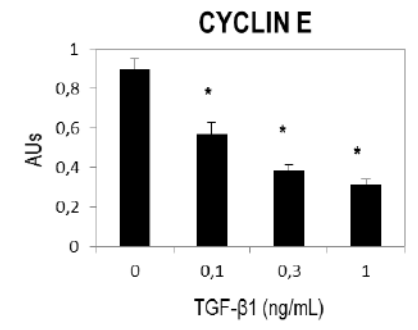

Fig. 3. TGF- $\beta$ induces cell cycle arrest in MDCK cells. MDCK cells were treated for 4 days with 0 (control) or $1 \mathrm{ng} / \mathrm{mL}$ TGF- 31 . At the end, cells were double stained for BrdU incorporation and DNA content, and the number of cells in each phase of the cell cycle was measured by flow cytometry (a representative experiment is shown on the left), and the average \pm SEM of $n=3$ independent experiments is shown on the right (a). Representative images of Western blot analysis ( of $n=3$ independent experiments) of cyclin $A$ and $E$ after 4 days of treatment with 0 or $1 \mathrm{ng} / \mathrm{mL}$ TGF- $\beta 1$ in MDCK, and the results of densitometric quantification of $\mathrm{n}=3$ independent experiments are shown (b). ${ }^{*} \mathrm{p}<0.05$ with respect to the control group. AUs, arbitrary unit.

TGF- $\beta 1$ reduces the proliferation of MDCK but not of HK2 cells

Incubation of MDCK cells with TGF- $\beta$ reduced proliferation in a concentration- and time-dependent manner (Fig. $2 \mathrm{~b}$ ). However, TGF- $\beta$ exerted no effect on the proliferation of 


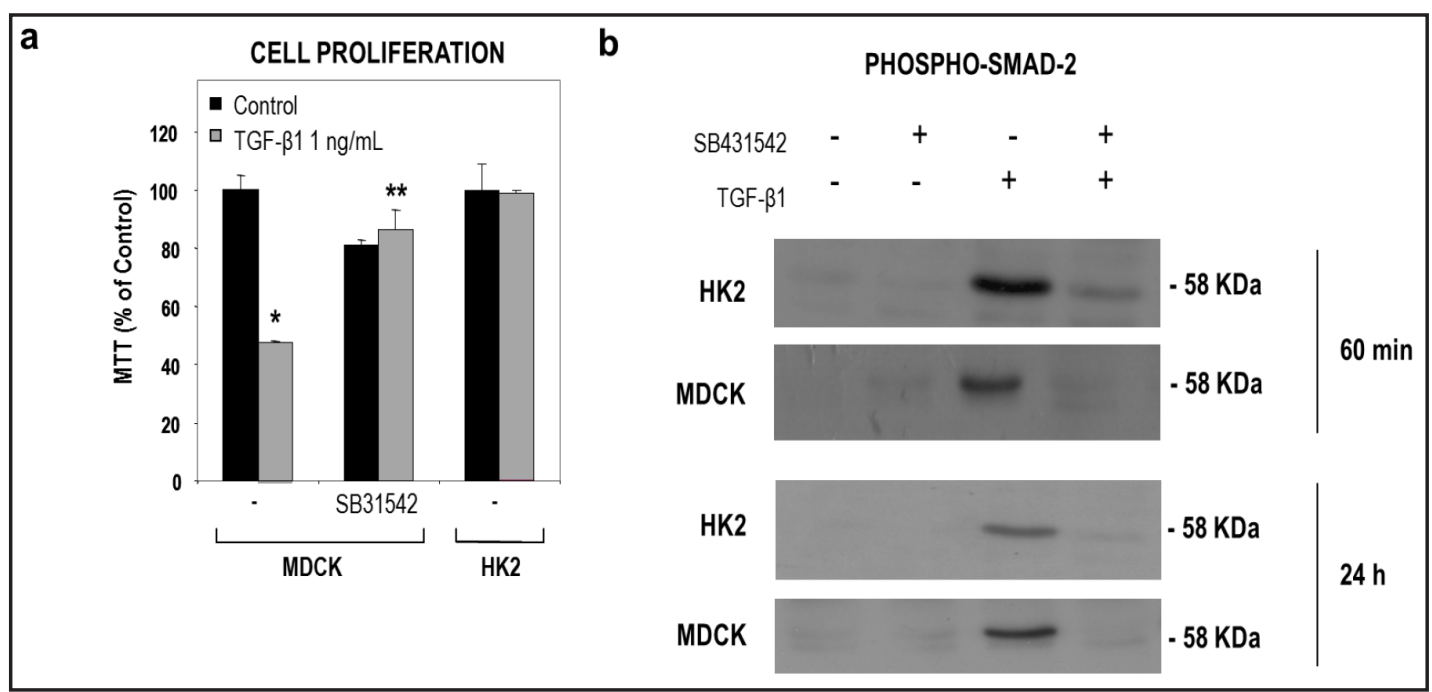

Fig. 4. The antiproliferative effect of TGF- $\beta 1$ in MDCK is dependent on the ALK- 5 pathway. MDCK and HK2 cells were treated with and without $1 \mathrm{ng} / \mathrm{mL}$ TGF- $\beta 1$ for $60 \mathrm{~min}$ and 24 hours in the presence or absence of the ALK-5 inhibitor SB431542 (0.5 $\mu \mathrm{M})$. At the end, a MTT assay was performed (a); and representative images Western blot analysis of the level of phospho-Smad-2 are shown (b). $n=3$ independent experiments were performed. MTT values show average \pm SEM. ${ }^{*} \mathrm{p}<0.05$ with respect to the control. ${ }^{* *} \mathrm{p}<0.01$ with respect to the MDCK-TGF- $\beta 1$ group.

HK2 cells (Fig. 2a). This antiproliferative effect on MDCK cells correlated with a cell cycle arrest in G0/G1 phase, as demonstrated by flow-cytometry analysis of PI-stained cells (Fig. 3a), and lower levels of cyclins E and A in MDCK cells, and not in HK2 cells (Fig. 3b).

The ALK-5 pathway is necessary for the antiproliferative effect of TGF- $\beta$ in MDCK cells but not in HK2 cells

The ALK-5 inhibitor SB431542 inhibits Smad-2 activation. This is shown by the inhibition of TGF- $\beta 1$-induced Smad-2 phosphorylation, both in MDCK and HK2 cells, as revealed by Western blot (Fig. 4b). Inhibition of the ALK-5 pathway with SB431542 inhibits the antiproliferative effect of TGF- $\beta 1$ of MDCK cells, and has no effect on the proliferation of HK2 cells (Fig. 4a). This indicates that activation of the ALK-5 pathway is necessary but not sufficient for the antiproliferative effect of TGF- $\beta 1$. In fact, the ALK-5/Smad-2 pathway is also fully activated in HK2 cells, with no consequence on cell proliferation.

The antiproliferative effect of TGF- $\beta$ is not associated to cell death

No cell death or apoptosis was induced by TGF- $\beta 1$ treatment in MDCK and HK2 cells, indicating that all the antiproliferative effect induced by this cytokine was due to cell cycle slow down. As shown in Fig. 5, no morphological signs of cell death or cell debris were observed after 4 days of treatment with TGF- $\beta 1$. No signs of nuclear alterations or internucleosomal DNA fragmentation (two hallmarks of apotosis) were detected by microscopy and ELISA, respectively (Fig. 5).

\section{Discussion}

In this study we show that activation of the ALK-5 pathway is necessary for the antiproliferative effect of TGF- $\beta 1$ in MDCK cells, but plays no role in HK2 cells. These findings indicate that the ALK-5-mediated pathways might be necessary for the antiproliferative effect of this cytokine on tubule cells; but also, that other determinants are necessary to be present or to be absent to allow TGF- $\beta 1$ to curtail tubule cell proliferation through ALK- 5 activation. 
Fig. 5. TGF- $\beta 1$ causes no signs of apoptosis. MDCK and HK2 cells were treated for 2, 3 and 4 days with 0 or $1 \mathrm{ng} / \mathrm{mL}$ TGF-ß1. Representative photographs (x200) of MDCK cells (light microscopy; and fluorescence microscopy upon nuclei staining with Hoestch 33342) after 4 days of treatment (a). Analysis by flow cytometry of number of MDCK cells with DNA content below the G0/G1 phase, as revealed by propidium iodide staining after 4 days of treatment (b). Internucleosomal DNA fragmentation measured by ELISA (c). Data show the average \pm SEM of $n=3$ independent experiments. AUs, arbitrary units. $\mathrm{C}+$, positive control.

Identification of mechanisms leading to proliferation of remnant tubular epithelial cells is a key to understanding normal and aberrant renal tissue repair, which in turn is key to understanding CKD progression $[11,18]$. TGF- $\beta$ has different biological functions, which occasionally result in opposed effects depending on the cell type and biological scenario. Overall, inhibition of TGF- $\beta$ action has proved beneficial effects in the context of both acute [19] and chronic $[2,20]$ renal damage. This benefit has been ascribed to the inhibition of the profibrotic and proapoptotic effects of TGF- $\beta$. TGF- $\beta$-induced fibrosis is well characterized, and has been recognized as an important mechanism of renal tissue derangement and scarring during CKD (reviewed in 2 and 20]. Direct induction of apoptosis by TGF- $\beta$ has been suggested [21], but also called into question [4]. TGF- $\beta$ exerts also an antiproliferative effect on many cell types and biological circumstances, although its role in the pathophysiology of renal damage has not been fully delineated. Probably, during a correct renal tissue repair course, TGF- $\beta$ may have an important role in, for example, stimulating the production of extracellular matrix components by re-differentiated tubular epithelial cells, in order to reconstitute the extracellular matrix and basement membrane [4, 22]. However, its presence must be avoided in other phases of the repair course, or its effects must be appropriately modulated or inhibited to obviate un-desired effects. In addition, the presence or effect of TGF- $\beta$ must terminate at due time in order to prevent tissue fibrosis and derangement. Other cytokines present both in normal and aberrant tissue repair are known to oppose and appropriately and timely modulate specific effects of TGF- $\beta$ [4]. These include bone morphogenetic protein 7 (BMP7) $[23,24]$ and hepatic growth factor (HGF) $[25,26]$. Accordingly, as a general concept, a cytokine imbalance may skew or even interrupt tissue repair at any stage of the course and contribute to the progression of CKD [27]. Interestingly, an agonist of the BMP7 receptor ALK-3 reduced renal injury in five different models of acute and chronic renal injury [23]. This protection was not exerted in animals genetically manipulated whose tubular epithelium lacked ALK-3 [23]. a
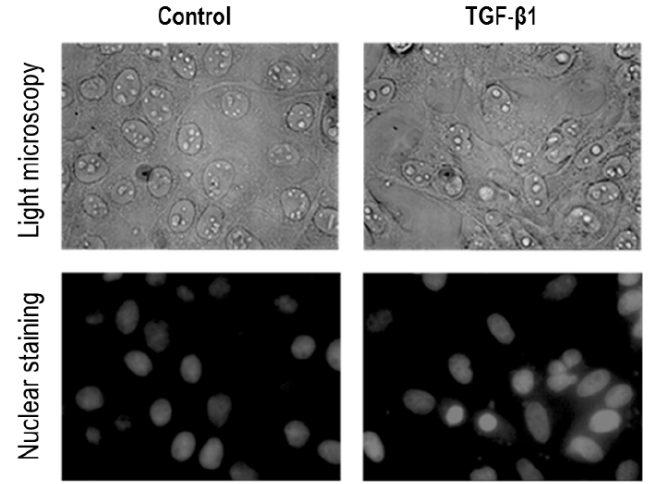

b

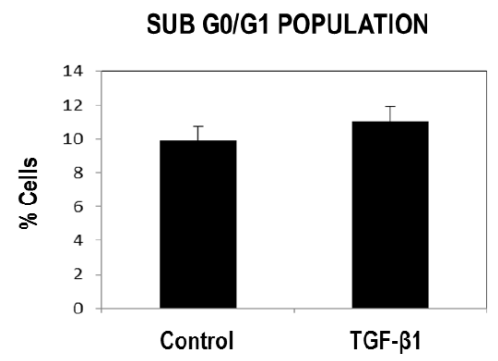

INTERNUCLEOSOMAL DNA FRAGMENTATION

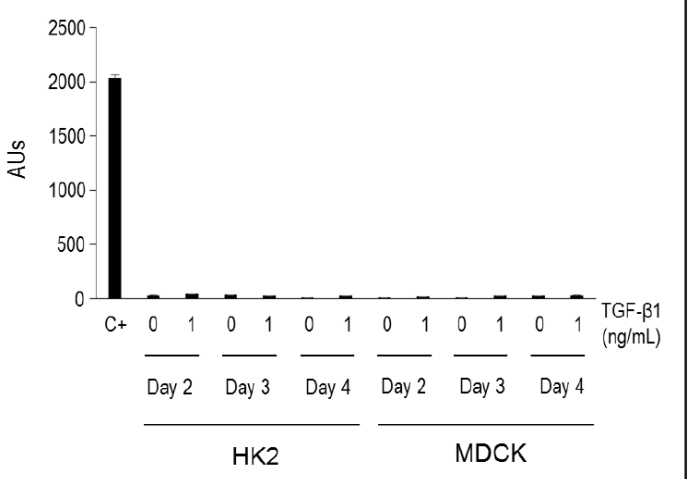

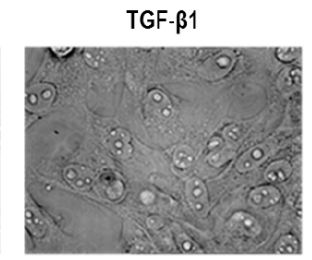




\section{Cellular Physiology Cell Physiol Biochem 2015;37:1231-1239 \begin{tabular}{l|l|l}
\hline DOI: 10.1159/000430246 & C 2015 S. Karger AG, Basel
\end{tabular} \begin{tabular}{l|l} 
and BiOchemistry Published online: October 05, 2015 & www.karger.com/cpb
\end{tabular} \\ García-Sánchez et al.: ALK-5 and TGF- $\beta$-Induced Cytostasis}

An excessive or insufficiently balanced presence of TGF- $\beta$ during the proliferation phase might cause skewing of tissue repair, which would lead to further fibrosis [4]. Our results indicate that activation of the Smad-2 pathway is critical for the antiproliferative effect of TGF- $\beta$ in MDCK cells. Inhibition of the Alk-5-Smad- 2 pathway abrogates the antiproliferative effect of TGF- $\beta$ in these cells. However, full activation of the Alk-5-Smad-2 pathway (up to gene expression modulation) has no effect on the proliferation of HK2 cells. This might indicate that the ALK-5-Smad-2 pathway is differently linked to other cellular mediators controlling cell proliferation in MDCK and HK2 cells. Or, alternatively, that additional conditions or mediators need to be present or absent in order for the ALK-5 pathway to mediate the antiproliferative effect of TGF- $\beta$. These additional players may be induced also by TGF- $\beta$ (differentially in each cell type); or they may be intrinsically specific of the cell strain, or be expressed or repressed differentially under determined circumstances. The final or net effect of TGF- $\beta$ is determined by the sum of the signals activated. In this sense signaling through the Smad pathway or the Ras-ERK pathway has been shown to be dependent on p53 [28]. For example, in the context of embryo development, TGF- $\beta$-induced cytostasis has been linked to its capacity to bind p53. In this situation, TGF- $\beta$-p53 interaction is only possible after N-terminal phosphorylation of p53, in a Ras/mitogen-activated protein kinase (MAPK)-dependent manner [29-31]. In our experimental system, the Ras-ERK pathways is not further activated by TGF- $\beta$ in any of the two cell lines, indicating that this is not the additional pathway controlling the effect of this cytokine of cell proliferation.

In conclusion, although the ALK-5 pathway appears to offer some potential as a target to modulate CKD progression, further investigation is needed to identify the circumstances that modulate the net effect of the ALK-5 pathway in normal human tubule epithelial cells and, importantly, also under CKD circumstances.

\section{Acknowledgements}

This work was supported by grans from Junta de Castilla y León [Consejería de Sanidad (80/A/2006) and Consejería de Educación (HUS02B06)].

\section{Disclosure Statement}

None.

\section{References}

1 James MT, Hemmelgarn BR, Tonelli M: Early recognition and prevention of chronic kidney disease. Lancet 2010:375:1296-1309.

2 López-Novoa JM, Rodríguez-Peña AB, Ortiz A, Martínez-Salgado C, López-Hernández FJ: Etiopathology of chronic tubular, glomerular and renovascular nephropathies: Clinical implications. J Trans Med 2001;9:13.

3 Fogo AB.: Mechanisms of progression of chronic kidney disease. Pediatr Nephrol 2007;22:2011-2022.

4 García-Sáchez 0, López-Hernández FJ, López-Novoa JM: An integrative view on the role of TGF- $\beta$ in the progressive tubular deletion associated with chronic kidney disease. Kidney Int 2010;77:950-955.

5 Remuzzi G, Benigni A, Remuzzi A: Mechanisms of progression and regression of renal lesions of chronic nephropathies and diabetes. J Clin Invest 2006;116:288-296.

6 De Vecchi AF, Dratwa M, Wiedemann ME: Healthcare systems and endstage renal disease (ESRD) therapies-an international review: costs and reimbursement/funding of ESRD therapies. Nephrol Dial Transplant 1999;14:31-41.

7 Docherty NG, Morales AI, López Novoa JM, Pérez Barriocanal F: La transición de células epiteliales a miofibroblastos. Mecanismos involucrados y su posible relación con la fibrosis renal. Nefrología 2007;27:681-688. 


\section{Cellular Physiology Cell Physiol Biochem 2015;37:1231-1239 \begin{tabular}{l|l|l}
\hline DOI: 10.1159/000430246 & (C) 2015 S. Karger AG, Basel
\end{tabular} www.karger.com/cpb

8 Yang J, Liu Y: Dissection of key events in tubular epithelial to myofibroblast transition and its implications in renal interstitialfibrosis. Am J Pathol 2001;159:1465-1475.

9 Ishibe S, Cantley LG: Epithelial-mesenchymal-epithelial cycling in kidney repair. Curr Opin Nephrol Hypertens 2008;17:379-385.

10 Yang L, Besschetnova TY, Brooks CR, Shah JV, Bonventre JV: Epithelial cell cycle arrest in G2/M mediates kidney fibrosis after injury. Nat Med 2010;16:535-543.

11 Yang L, Humphreys BD, Bonventre JV: Pathophysiology of acute kidney injury to chronic kidney disease: maladaptive repair. Contrib Nephrol 2011;174:149-155.

12 Lan A, Qi Y, Du J: Akt2 mediates TGF- $\beta 1$-induced epithelial to mesenchymal transition by deactivating GSK3 $\beta$ /snail signaling pathway in renal tubular epithelial cells. Cell Physiol Biochem 2014;34:368-382.

13 Massague J: TGF-beta signal transduction. Annu Rev Biochem. 1998;67:753-791.

14 Shi Y, Massague J: Mechanisms of TGF-beta signaling from cell membrane to the nucleus. Cell 2003;113:685-700.

15 Siegel PM, Massague J: Cytostatic and apoptotic actions of TGF-beta in homeostasis and cancer. Nat Rev Cancer 2003;3:807-820.

16 Li Y, Tan X, Dai C, Stolz DB, Wang D, Liu Y: Inhibition of integrin-linked kinase attenuates renal interstitial fibrosis. J Am Soc Nephrol 2009;20:1907-1918.

17 Lebrin F, Deckers M, Bertolino P, Ten Dijke P: TGF-beta receptor function in the endothelium. Cardiovasc Res 2005;65:599-608.

18 Bonventre JV: Pathophysiology of acute kidney injury: roles of potential inhibitors of inflammation. Contrib Nephrol 2007;156:39-46.

19 Gewin L, Vadivelu S, Neelisetty S, Srichai MB, Paueksakon P, Pozzi A, Harris RC, Zent R: Deleting the TGF- $\beta$ receptor attenuates acute proximal tubule injury. J Am Soc Nephrol 2012;23:2001-2011.

20 López-Novoa JM, Martínez-Salgado C, Rodríguez-Peña AB, López-Hernández FJ: Common pathophysiological mechanisms of chronic kidney disease: therapeutic perspectives. Pharmacol Ther 2010;128:61-81.

21 Docherty NG, O'Sullivan OE, Healy DA, Murphy M, O'neill AJ, Fitzpatrick JM, Watson RW: TGF-beta1-induced EMT can occur independently of its proapoptotic effects and is aided by EGF receptor activation. Am J Physiol Renal Physiol 2006;290:F1202-1212.

22 Wen X, Murugan R, Peng Z, Kellum JA: Pathophysiology of acute kidney injury: a new perspective. Contrib Nephrol 2010;165:39-45.

23 Sugimoto H, LeBleu VS, Bosukonda D, Keck P, Taduri G, Bechtel W, Okada H, Carlson W Jr, Bey P, Rusckowski M, Tampe B, Tampe D, Kanasaki K, Zeisberg M, Kalluri R: Activin-like kinase 3 is important for kidney regeneration and reversal of fibrosis. Nat Med 2012;18:396-404.

24 Meng XM, Chung AC, Lan HY: Role of the TGF- $\beta$ /BMP-7/Smad pathways in renal diseases. Clin Sci (Lond) 2013;124:243-254.

25 Mizuno S, Matsumoto K, Kurosawa T, Mizuno-Horikawa Y, Nakamura T: Reciprocal balance of hepatocyte growth factor and transforming growth factor-beta 1 in renal fibrosis in mice. Kidney Int 2000;57:937-948.

26 Matsumoto K, Nakamura T: Renotropic role and therapeutic potential of HGF in the kidney. Nephrol Dial Transplant 2002;17:59-61.

27 Carrero JJ, Park SH, Axelsson J, Lindholm B, Stenvinkel P: Cytokines, atherogenesis, and hypercatabolism in chronic kidney disease: a dreadful triad. Semin Dial 2009;22:381-386.

28 Lin S, Yu L, Yang J, Liu Z, Karia B, Bishop AJ, Jackson J, Lozano G, Copland JA, Mu X, Sun B, Sun LZ: Mutant p53 disrupts role of ShcA protein in balancing Smad protein-dependent and -independent signaling activity of transforming growth factor- $\beta$ (TGF- $\beta$ ). J Biol Chem 2011;286:44023-44034.

29 Cordenonsi M, Dupont S, Maretto S, Insinga A, Imbriano C, Piccolo S. Links between tumor suppressors: p53 is required for TGF-beta gene responses by cooperating with Smads. Cell 2003;113:301-314.

30 Dupont S, Zacchigna L, Adorno M, Soligo S, Volpin D, Piccolo S, Cordenonsi M: Convergence of p53 and TGFbeta signaling networks. Cancer Lett 2004;213:129-138.

31 Cordenonsi M, Montagner M, Adorno M, Zacchigna L, Martello G, Mamidi A, Soligo S, Dupont S, Piccolo S: Integration of TGF-beta and Ras/MAPK signaling through p53 phosphorylation. Science 2007;315:840843. 